Le Centre de santé communautaire du Pontiac (CSCP) est à la recherche d'un

\section{ANESTHÉSISTE} (temps partiel)

Le CSCP, un établissement qui privilégie l'excellence dans la pratique de la médecine rurale, regroupe un CLSC, un CHSCD et trois centres d'accueil.

- Remplacement au per diem ( 3 semaines/3 mois)

- Garde partagée avec omni-anesthésiste

- Chirurgie d'un jour, chirurgie générale, soins intensifs

- Rémunération majorée: $120 \%$

-20 jours de ressourcement payés par année

\section{Pour de plus amples renseignements,} je vous prie de contacter le:

$D^{r}$ John C.S. Wootton

Directeur des services professionnels

Centre de santé communautaire du Pontiac 200, rue Argue

Shawville (Québec) JOX 2Y0

(819) 647-2211

email: jwootton@fox.nstn.ca

\section{NEUROANAESTHETIST REQUIRED}

The Department of Anaesthesis at The Toronto Hospital, University of Toronto is accepting applications for a neuroanaesthesia staff position. Position available immediately. The Toronto Hospital is a major teaching hospital at the University of Toronto, and has a large neurosurgical service, with approximately 1800 cases per year. This staff position offers both clinical and research opportunities in neuroanaesthesia, neuro ICU, pharmacology and physiology. Applicants must be Canadian certified in anaesthesia.

\section{Interested individuals should send curriculum vitae or contact:}

Dr. Alan Sandler, Anaesthetist-in-Chief Toronto Hospital, General Division, BW 4-631

200 Elizabeth Street, Toronto, Ontario Canada M5G 2C4

Telephone (416) 340-3227

Fax: (416) 340-3698

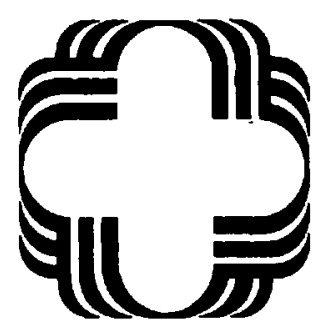

\title{
ANAESTHESIA OPPORTUNITY IN SOUTHWESTERN ONTARIO
}

\section{REGIONAL HEALTH CENTRE}

The Grey Bruce Regional Health Centre in Owen Sound, Ontario requires a fellowship anaesthetist by October 1, 1996. This position could be permanent or a long term locum, and represents a replacement.

The hospital provides approximately 9,000 anaesthetics each year for a wide variety of surgical specialties, including general and vascular surgery, orthopedics, ENT, urology, ophthalmology, obstetrics and gynecology. There is a Pain Clinic and a busy ICU.

The Department of Anaesthesia consists of 5 full-time members and one part-time member. Call is on a one in five rota.

If you are interested in more details about this excellent opportunity, please contact:

Dr. Robert Severs or Dr. Gordon Edwards

at the hospital (519) 376-2121 